\title{
PENGARUH PEMBERIAN SEDUHAN DAUN KELOR TERHADAP KUANTITAS AIR SUSU IBU (ASI) PADA IBU MENYUSUI BAYI 0-6 BULAN DI WILAYAH KERJA PUSKESMAS SUMUR BATU KOTA BANDAR LAMPUNG
}

\author{
Eka Trismiyana ${ }^{1}$, Mei Kurnia Pitaloka ${ }^{2}$
}

${ }^{1}$ Dosen Keperawatan Universitas Malahayati Bandar Lampung

Email: ekatrismiyana@gmail.com

${ }^{2}$ Mahasiswi keperawatan Universitas Malahayatl Bandar Lampung

Email : mei722482@gmail.com

\section{THE EFFECT OF GIVING KELOR LEAVES TOWARDS MILK (ASI) WATER QUANTITY IN 0-6 MONTHS OF BABY BREAST MILK IN WORKING AREAS OF HEALTH CENTER OF BATU BANDAR LAMPUNG CITY}

Introduction: Bandar Lampung City Health Office data shows that there are 3 Puskesmas with the lowest ASI coverage, namely Sumur Batu Health Center, with a total of 6 months exclusive breastfeeding coverage 142, as many as 102 infants (28.17\%) did not receive exclusive breastfeeding at 6 months of age, and 40 ASI received exclusive breastfeeding, Way Kandis Health Center, with a total of 6 months exclusive breastfeeding coverage in 919, 621 infants (32.93\%) did not receive exclusive breastfeeding aged 6 months, and 298 ASIs received exclusive breastfeeding, Kemiling Health Center, with total breastfeeding coverage exclusive 6 months 98, 62 babies (36.73\%) did not get exclusive breastfeeding at the age of 6 months, and 36 ASIs received exclusive breastfeeding (Data from Bandar Lampung City Health Office, 2018).

Objective: To determine the effect of administration of Moringa leaves on the quantity of breast milk in breastfeeding mothers of infants 0-6 months in the Work Area of Sumur Batu Health Center, Bandar Lampung City in 2019.

Method: This type of research is quantitative. The design of the Quasi Experimental method is one group pretest-posttest one group pretest-posttest approach. Population and sample of 30 people. Data analysis uses univariate and bivariate with t-test.

Results: The average quantity of breast milk in breastfeeding mothers of infants 0-6 months before being given moringa leaf steeping in the Sumur Batu Health Center Working Area, with a mean of 72.50 standard deviation 25.317 standard error 4.622, after being given steeping leaves of moringa mean 97.17 standard deviation of 17.601 standard error 3.214. P-value 0,000 $(<0.05) t$-test test results.

Conclusion: means that there is an effect of steeping Moringa leaves on the quantity of breast milk in breastfeeding mothers of infants 0-6 months in the Sumur Batu Community Health Center Working Area in Bandar Lampung City in 2019. Suggestions for respondents are expected to be used as input for clients in order to know how to increase the smoothness of breast milk during breastfeeding.

Keywords: Moringa Leaf Steeping, Breast Milk, Breastfeeding Mother

Eka Trismiyana ${ }^{1}$, Mei Kurnia Pitaloka ${ }^{2}$

${ }^{1}$ Dosen Keperawatan Universitas Malahayati Bandar Lampung. Email: ekatrismiyana@gmail.com

${ }^{2}$ Mahasiswi keperawatan Universitas Malahayatl Bandar Lampung. Email : mei722482@gmail.com 


\section{INTISARI: PENGARUH PEMBERIAN SEDUHAN DAUN KELOR TERHADAP KUANTITAS AIR SUSU IBU (ASI) PADA IBU MENYUSUI BAYI 0-6 BULAN DI WILAYAH KERJA PUSKESMAS SUMUR BATU KOTA BANDAR LAMPUNG}

Pendahuluan: Data Dinas Kesehatan Kota Bandar Lampung menunjukan bahwa terdapat 3 Puskesmas dengan cakupan pemberian ASI terendah yaitu, Puskesmas Sumur Batu, dengan total keseluruhan cakupan ASI eksklusif 6 bulan 142, sebanyak 102 bayi (28.17\%) tidak mendapat ASI eksklusif usia 6 bulan, dan 40 ASI mendapat ASI eksklusif, Puskesmas Way Kandis, dengan total keseluruhan cakupan ASI eksklusif 6 bulan 919, sebanyak 621 bayi (32.93\%) tidak mendapat ASI eksklusif usia 6 bulan, dan 298 ASI mendapat ASI eksklusif, Puskesmas Kemiling, dengan total keseluruhan cakupan ASI eksklusif 6 bulan 98 , sebanyak 62 bayi (36.73\%) tidak mendapat ASI eksklusif usia 6 bulan, dan 36 ASI mendapat ASI eksklusif (Data Dinkes Kota Bandar Lampung, 2018).

Tujuan: Untuk mengetahui pengaruh pemberian seduhan daun kelor terhadap kuantitas air susu ibu (ASI) pada ibu menyusui bayi 0-6 bulan di Wilayah Kerja Puskesmas Sumur Batu Kota Bandar Lampung tahun 2019.

Metode: Jenis penelitian ini adalah Kuantitatif. Desain penelitian metode Quasi Eksperimental pendekatan one group pretes-postes one group pretespostes. Populasi dan sampel 30 orang. Analisa data mengguanakan univariat dan bivariate dengan $t$-tes.

Hasil : Rata-rata kuantitas air susu ibu (ASI) pada ibu menyusui bayi 0-6 bulan sebelum diberi seduhan daun kelor di Wilayah Kerja Puskesmas Sumur Batu, dengan mean 72,50 standar deviasi 25,317 standar eror 4,622, setelah diberi seduhan daun kelor mean 97,17 standar deviasi 17,601 standar eror 3,214. Hasil uji t-tes $p$-value $0.000(<0.05)$.

Kesimpulan : artinya terdapat pengaruh pemberian seduhan daun kelor terhadap kuantitas air susu ibu (ASI) pada ibu menyusui bayi 0-6 bulan di Wilayah Kerja Puskesmas Sumur Batu Kota Bandar Lampung Tahun 2019. Saran bagi responden diharapkan hasil penelitian ini dapat digunakan sebagai masukan bagi klien agar dapat mengetahui bagaimana cara menambah kelancaran ASI pada masa menyusui.

Kata Kunci : Seduhan Daun Kelor, ASI, Ibu Menyusui

\section{PENDAHULUAN}

Badan kesehatan World Health Organization (WHO) dan United Nations International Children's Emergency Fund (UNICEF) merekomendasikan: inisiasi menyusu dini dalam waktu 1 jam dari lahir; ASI eksklusif selama 6 bulan pertama kehidupan; dan pengenalan nutrisi yang memadai dan aman komplementer (padat) makanan pada 6 bulan bersama dengan terus menyusui sampai 2 tahun atau lebih. Namun, banyak bayi dan anak-anak tidak menerima makan optimal, dimana hanya sekitar 36\% dari bayi usia 0 sampai 6 bulan di seluruh dunia yang diberikan ASI eksklusif selama periode tahun 2007 sampai dengan tahun 2014 (WHO, 2016).

Cakupan pemberian ASI di Indonesia pada tahun 2015 sebesar $55,7 \%$ dan pada jika mengacu pada target RENSTRA pada tahun 2015 yang sebesar 39\%, maka secara nasional cakupan pemberian ASI eksklusif pada bayi usia kurang dari

Eka Trismiyana ${ }^{1}$, Mei Kurnia Pitaloka ${ }^{2}$

${ }^{1}$ Dosen Keperawatan Universitas Malahayati Bandar Lampung. Email: ekatrismiyana@gmail.com

${ }^{2}$ Mahasiswi keperawatan Universitas Malahayatl Bandar Lampung. Email : mei722482@gmail.com 
enam bulan telah mencapai target. Menurut provinsi, kisaran cakupan ASI eksklusif pada bayi umur 0-6 bulan antara 26,3\% (Sulawesi Utara) sampai $86,9 \%$ (Nusa Tenggara Barat). Dari 33 provinsi yang melapor, sebanyak 29 di antaranya (88\%) berhasil mencapai target renstra 2015 (Kemenkes RI, 2016). Sedangkan Pada tahun 2016 di Indonesia diketahui bahwa jumlah persentase bayi mendapat ASI eksklusif sampai usia 6 bulan sebesar $29,5 \%$ dan bayi yang mendapat ASI usia 0-5 bulan sebesar 54 ,0\% (Kemenkes RI, 2017).

Tujuan dari pembangunan kesehatan salah satunya adalah menurunkan angka kematian bayi. Angka Kematian Bayi menurut Sustainanble Depelovment Goals (SDGs) tahun 2015 berjumlah 40 per 1000 kelahiran hidup dan masih menempati peringkat ke-4 tertinggi kematian bayi se-ASEAN. Angka kematian bayi (AKB) adalah jumlah kematian bayi dalam usia 28 hari pertama kehidupan per 1.000 kelahiran hidup (Kementerian Kesehatan RI, 2015) Penyebab kematian bayi terbesar di Indonesia adalah kematian neonatal dan dua pertiga dari kematian neonatal adalah pada satu minggu pertama dimana daya imun bayi masih sangat rendah. Angka kematian bayi yang cukup tinggi dapat dihindari dengan pemberian air susu ibu (ASI). Banyak penelitian yang dilakukan, tehnologi canggih digunakan, namun tindakan preventif yang paling ampuh dilakukan untuk menyelamatkan bayi-bayi Indonesia adalah melakukan Inisiasi Menyusui Dini (IMD) dan memberikan ASI eksklusif (Moascara, 2011).

Target ASI eksklusif di Bandar Lampung sebesar $40 \%$, berdasarkan data dinas kesehatan Kota Bandar
Lampung menunjukan bahwa terdapat 3 Puskesmas dengan cakupan pemberian ASI terendah yaitu, Puskesmas Sumur Batu, dengan total keseluruhan cakupan ASI eksklusif 6 bulan 142, sebanyak 102 bayi $(28.17 \%)$ tidak mendapat ASI eksklusif usia 6 bulan, dan 40 bayi mendapat ASI eksklusif, Puskesmas Way Kandis, dengan total keseluruhan cakupan ASI eksklusif 6 bulan 919, sebanyak 621 bayi (32.93\%) tidak mendapat ASI eksklusif usia 6 bulan, dan 298 bayi mendapat ASI eksklusif, Puskesmas Kemiling, dengan total keseluruhan cakupan ASI eksklusif 6 bulan 98 bayi sebanyak 62 bayi (36.73\%) tidak mendapat ASI eksklusif usia 6 bulan, dan 36 bayi mendapat ASI eksklusif (Data Dinkes Kota Bandar Lampung, 2018).

Studi tentang pemberian tepung daun kelor oleh Idohondossou secara acak terhadap dua kelompok ibu menyusui yang memiliki bayi 3-4 bulan yang masing-masing diberikan tepung daun kelor dan tablet besi/asam folat (kontrol), setelah tiga bulan terapi, rata-rata kadar konsentrasi $\mathrm{Hb}$ meningkat secara signifikan baik kelompok perlakuan maupun kontrol, meskipun kadar ferritin plasma tidak signifikan pada kelompok yang mendapat tepung kelor.Selanjutnya Titi Mutiara menyimpulkan bahwa daun kelor merupakan bahan makanan yang dapat meningkatkan produksi ASI (Zakaria, 2016).

Disamping itu, daun kelor juga mengandung semua unsur asam amino yang penting (essensial). Berbagai nutrisi ini merupakan suatu sumber yang luar biasa dari tumbuhan. Kecuali vitamin C, semua kandungan gizi yang terdapat dalam daun kelor segar akan mengalami peningkatan

Eka Trismiyana ${ }^{1}$, Mei Kurnia Pitaloka ${ }^{2}$

${ }^{1}$ Dosen Keperawatan Universitas Malahayati Bandar Lampung. Email: ekatrismiyana@gmail.com

${ }^{2}$ Mahasiswi keperawatan Universitas Malahayatl Bandar Lampung. Email : mei722482@gmail.com 
konsentrasinya) apabila dikonsumsi setelah dikeringkan dan dilumatkan dalam bentuk serbuk atau tepung. Satu sendok makan bubuk daun kelor berisi $14 \%$ protein, kalsium, zat besi dan provitamin A. Enam sendok makan bubuk daun kelor dapat memenuhi kebutuhan harian kalsium dan zat besi bagi hamil dan menyusui (Lowell, 2004; Balbir, 2011; Deptan, 2012).

Daun kelor yang berwarna hijau kering diekstrak dengan menggunakan ethanol $80 \%$, maserasi dilakukan selama 24 jam, ekstrak dirotavapor pada suhu $500 \mathrm{C}$ selama $2 \times 24$ jam. Hasilnya dikeringkan secara beku (freeze dryer) selama $2 \times 24$ jam. Hasil ekstrak dicampurkan dengan tepung kelor dengan perban- dingan 1:4 kemudian dimasukkan menjadi satu kapsul ekstrak kelor dengan berat $800 \mathrm{mg}$. Setiap kapsul ekstrak kelor mengandung protein $0,10 \mathrm{~g}$, lemak $0,15 \mathrm{~g}$, vitamin $\mathrm{A} 2,5 \mu \mathrm{g}$, vitamin $\mathrm{E}$ $11,72 \mathrm{mg}$, vitamin C $10,25 \mathrm{mg}$, dan besi 0,08mg; dan kapsul tepung kelor mengandung protein $0,22 \mathrm{~g}$, lemak $0,02 \mathrm{~g}$, vitamin $\mathrm{A} 0,13 \mu \mathrm{g}$, vitamin $E \quad 0,90 \mathrm{mg}$, vitamin $C$ $0,14 \mathrm{mg}$, dan besi $0,28 \mathrm{mg}$ (Zakaria, 2016).

Berdasarkan hasil prasurvey di Wilayah Kerja Puskesmas Sumur Batu dengan melakukan wawancara bebas terhadap $10 \mathrm{ibu}, 6$ orang ibu
(60\%) menyatakan jika tidak memberikan anaknya ASI eksklusif selama 6 bulan, karena ASI ibu kurang lancar, sehingga ibu memberikan tambahan susu formula ataupun teh, serta makanan seperti pisang lumat. Sedangkan 4 ibu (40\%) hanya memberikan ASI sampai anak usia 6 bulan.

Berdasarkan uraian tersebut, maka penulis termotivasi untuk melakukan penelitian tentang: pengaruh pemberian seduhan daun kelor terhadap kuantitas dan kualitas air susu ibu (ASI) pada ibu menyusui bayi 0-6 bulan di Wilayah Kerja Puskesmas Sumur Batu Kota Bandar Lampung tahun 2019.

\section{METODE PENELITIAN}

Jenis penelitian ini merupakan jenis penelitian kuantitatif. Rancangan dalam penelitian ini menggunakan desainQuasi Eksperimental dengan pendekatan one group pretest - posttest design. Sampel dalam penelitian ini adalah kelompok 1: 1 sebanyak 30 responden yang dibagi kedalam 2 kelompok perlakuan yaitu 15 kelompok intervensi, dan 15 kelompok kontrol dan pada 1 kelompok perlakuan menggunakan sampel minimal 15-25 responden. Pengolahan data menggunakan aplikasi SPSS versi 20.

HASIL

Analisa Univariat

Tabel 1.

Rata-Rata Kuantitas Air Susu Ibu (ASI) Pada Ibu Menyusui Bayi 0-6 Bulan Sebelum Diberi Seduhan Daun Kelor Di Wilayah Kerja Puskesmas Sumur Batu Kota Bandar Lampung

\begin{tabular}{lccrcc}
\hline Kuantitas ASI & N & Mean & Std. Dev & SE & Min-Max \\
\hline Sebelum Intevensi & 30 & 72,50 & 25,317 & 4,622 & $30-110$ \\
\hline
\end{tabular}

Eka Trismiyana ${ }^{1}$, Mei Kurnia Pitaloka ${ }^{2}$

${ }^{1}$ Dosen Keperawatan Universitas Malahayati Bandar Lampung. Email: ekatrismiyana@gmail.com

${ }^{2}$ Mahasiswi keperawatan Universitas Malahayatl Bandar Lampung. Email : mei722482@gmail.com 
Dari table diatas dapat diketahui bahwa rata-rata kuantitas air susu ibu (ASI) pada ibu menyusui bayi 0-6 bulan sebelum diberi seduhan daun kelor di Wilayah Kerja Puskesmas
Sumur Batu Kota Bandar Lampung Tahun 2019, dengan mean 72,50 standar deviasi 25,317 standar eror 4,622 min $30 \max 110$.

Tabel 2.

Rata-Rata Kuantitas Air Susu Ibu (ASI) Pada Ibu Menyusui Bayi 0-6 Bulan Sebelum Diberi Seduhan Daun Kelor Di Wilayah Kerja Puskesmas Sumur Batu Kota Bandar Lampung

\begin{tabular}{lccrcc}
\hline Kuantitas ASI & N & Mean & Std. Dev & SE & Min-Max \\
\hline Sesudah Intevensi & 30 & 97,17 & 17,601 & 3,214 & $60-130$ \\
\hline
\end{tabular}

Dari tabel diatas dapat diketahui bahwa rata-rata kuantitas air susu ibu (ASI) pada ibu menyusui bayi 0-6 bulan sesudah diberi seduhan daun kelor di Wilayah Kerja Puskesmas

\section{Analisis Bivariat}

Tabel 3.

Pengaruh Pemberian Seduhan Daun Kelor Terhadap Kuantitas Air Susu Ibu (ASI) Pada Ibu Menyusui Bayi 0-6 Bulan Di Wilayah Kerja Puskesmas Sumur Batu Kota Bandar Lampung

\begin{tabular}{|c|c|c|c|c|c|c|c|}
\hline Kuantitas ASI & $\mathbf{N}$ & Mean & SD & SE & P-Value & \multicolumn{2}{|c|}{$\frac{C I 95 \%}{\text { Min-Max }}$} \\
\hline Sebelum & 30 & 72,50 & 25,317 & 4,622 & \multirow{3}{*}{0.001} & 30 & 110 \\
\hline Sesudah & 30 & 97,17 & 17,601 & 3,214 & & 60 & 130 \\
\hline Selisih & & 24,67 & 17,466 & 3,189 & & & \\
\hline
\end{tabular}

Dari tabel terlihat bahwa perbedaan perlakuan dengan 30responden pada kuantitas ASI sebelum diberi seduhan daun kelor dengan mean 72,50 standar deviasi 25,317 standar eror 4,622dan setelah diberi seduhan daun kelor dengan mean 97,17 standar deviasi 17,601 standar eror 3,214 dengan selisih mean -24,667 standar deviasi

17,466 dan standar eror 3,189
Sumur Batu Kota Bandar Lampung Tahun 2019, dengan mean 97,17 standar deviasi 17,601 standar eror 3,214 min $60 \max 130$.

dengan selisih mean pretes-postes 24,67 nilai rata-rata kuantitas ASI pretes postes terendah $30-110$

Hasil P-Value $0.000 \quad(<0.05)$ yang artinya terdapat pengaruh pemberian seduhan daun kelor terhadap kuantitas air susu ibu (ASI) pada ibu menyusui bayi 0-6 bulan di Wilayah Kerja Puskesmas Sumur Batu Kota Bandar Lampung Tahun 2019

Eka Trismiyana ${ }^{1}$, Mei Kurnia Pitaloka ${ }^{2}$

${ }^{1}$ Dosen Keperawatan Universitas Malahayati Bandar Lampung. Email: ekatrismiyana@gmail.com ${ }^{2}$ Mahasiswi keperawatan Universitas Malahayatl Bandar Lampung. Email : mei722482@gmail.com 
Pembahasan

Analisis Univariat

1. Rata-Rata Kuantitas Air Susu Ibu (ASI) Pada Ibu Menyusui Bayi 0-6 Bulan Sebelum Diberi Seduhan Daun Kelor Di Wilayah Kerja Puskesmas Sumur Batu Kota Bandar Lampung Tahun 2019

Dari table diatas dapat diketahui bahwa rata-rata kuantitas air susu ibu (ASI) pada ibu menyusui bayi 0-6 bulan sebelum diberi seduhan daun kelor di Wilayah Kerja Puskesmas Sumur Batu Kota Bandar Lampung Tahun 2019, dengan mean 72,50 standar deviasi 25,317 standar eror 4,622 min $30 \max 110$.

Sejalan dengan teori yang dikemukakan oleh Maryunani (2015)Produksi ASI merupakan proses laktasi atau menyusui adalah proses pembentukan ASI yang melibatkan hormon prolaktin dan hormon oksitosin. Pada fase ini kolostrum yang keluar pada saat hamil atau sebelum bayi lahir tidak menjadikan masalah sedikit atau banyaknya ASI yang akan di produksi. Produksi ASI bergantung pada kerja hormone dan reflek menyusui. Selama kehamilan terjadi perubahan pada hormone yang berfungsi mempersiapkan kelenjar susu untuk memproduksi ASI. Segera setelah melahirklan, bahkan dimulai sejak usia kehamilan 6 bulan, terjadi perubvahan hormonal yang menyebabkan payudara mulai memproduksi ASI.

Penelitian yang dilakukan oleh Zakaria (2016)Pengaruh Pemberian Ekstrak Daun Kelor
TerhadapKuantitas Dan Kualitas Air Susu Ibu (Asi) Padalbu Menyusui Bayi 0-6 Bulan. Analisis statistikmenggunakan uji $\mathrm{t}$ sampel berpasangan dan bebas. Kuantitas ASI meningkat pada kedua kelompok EK (397 \pm 118 menjadi $661 \pm 158$, $\mathrm{p}=0,001)$ dan TK $(449 \pm 129$ to $600 \pm 120, p=0,001)$.

Menurut peneliti, produksi ASI merupakan tahap keberhasilan ibu memberikan nutrisi kepada anaknya, bila ibu mengalami kekurangan ASI yang menyebabkan ASI tidak lancar, maka ibu dikatakan tidak berhasil dalam memberikan nutrisi kepada bayi tersebut, dalam penelitian ini didapat hasil dari 30 responden 23 ibu tidak lancar ASI dengan rentang ASI sebanyak 30-90cc, dan $7 \mathrm{ibu}$ lancar ASI sebanyak 100-110cc.

2. Rata-Rata Kuantitas Air Susu Ibu (ASI) Pada Ibu Menyusui Bayi 0-6 Bulan Sesudah Diberi Seduhan Daun Kelor Di Wilayah Kerja Puskesmas Sumur Batu Kota Bandar Lampung Tahun 2019

Dari tabel diatas dapat diketahui bahwa rata-rata kuantitas air susu ibu (ASI) pada ibu menyusui bayi 0-6 bulan sesudah diberi seduhan daun kelor di Wilayah Kerja Puskesmas Sumur Batu Kota Bandar Lampung Tahun 2019, dengan mean 97,17 standar deviasi 17,601 standar eror 3,214 min 60 max 130 .

Sejalan dengan teori yang dikemukakan oleh Maryunani (2015) Sejumlah kecil produk dalam payudara mulai terkumpul selama kehamilan itu sendiri. Namun, pengeluaran

Eka Trismiyana1 ${ }^{1}$ Mei Kurnia Pitaloka ${ }^{2}$

${ }^{1}$ Dosen Keperawatan Universitas Malahayati Bandar Lampung. Email: ekatrismiyana@gmail.com

${ }^{2}$ Mahasiswi keperawatan Universitas Malahayatl Bandar Lampung. Email : mei722482@gmail.com 
ASI yang sesungguhnya akan dimulai dalam waktu tiga hari setelah persalinan. Hal ini terjadi karena selama kehamilan hormon kewanitaan progesteron dan estrogen membuat payudara tidak responsif terhadap prolaktin. Setelah persalinan, ketika kedua hormon kewanitaan ini berkurang, payudara yang telah berkembang sepenuhnya mulai mengeluarkan ASI sebagai akibat dari tindakan prolaktin.

Penelitian yang dilakukan oleh Zakaria (2016)Pengaruh Pemberian Ekstrak Daun Kelor TerhadapKuantitas Dan Kualitas Air Susu Ibu (Asi) Padalbu Menyusui Bayi 0-6 Bulan. Analisis statistikmenggunakan uji $\mathrm{t}$ sampel berpasangan dan bebas. Kuantitas ASI meningkat pada kedua kelompok EK (397 \pm 118 menjadi $\quad 661 \pm 158$, $\mathrm{p}=0,001)$ dan TK $(449 \pm 129$ to $600 \pm 120, p=0,001)$. Menurut

peneliti, kelancaran ASI dapat dipengaruhi oleh beberapa hal, seperti frekuensi memberikan ASI, makanan yang dikonsumsi hingga pola istirahat, pada penelitian ini dapat dilihat jika terdapat pengaruh antara produksi ASI sebelum dan sesudah diberikan seduhan daun kelor, pada penelitian ini terdapat peningkatan ASI yang signifikan sebelum dan sesudah diantaranya ada 17 responden dengan jumlah pengeluaran ASI 100-1200cc, sedangkan 13 orang mengalami peningkatan ASI namun tidak signifikan, karena pengeluaran ASI hanya 60-90cc. Daun kelor sangat kaya akan nutrisi, diantaranya kalsium, besi, protein, vitamin A, vitamin B dan vitamin C.
Daun kelor mengandung zat besi lebih tinggi daripada sayuran lainnya yaitu sebesar 17,2 mg/100 g (Yameogo et al. 2011) Daun kelor terlebih dahulu diekstraksi dengan menggunakan pelarut etanol $96 \%$, kemudian dilakukan uji fitokimia untuk mendeteksi adanya senyawa aktif alkaloid, flavonoid, saponin, fenolat, triterpenoida/steroida, dan tannin (Putra,2016).

\section{Analisa Bivariat}

1. Pengaruh Pemberian Seduhan Daun Kelor Terhadap Kuantitas Air Susu Ibu (ASI) Pada Ibu Menyusui Bayi 0-6 Bulan Di Wilayah Kerja Puskesmas Sumur Batu Kota Bandar Lampung Tahun 2019

Dari tabel terlihat bahwa perbedaan perlakuan dengan 30 responden pada kuantitas ASI sebelum diberi seduhan daun kelor dengan mean 72,50 standar deviasi 25,317 standar eror 4,622dan setelah diberi seduhan daun kelor dengan mean 97,17 standar deviasi 17,601 standar eror 3,214 dengan Hasil P-Value $0.000 \quad(<0.05)$ yang artinya terdapat pengaruh pemberian seduhan daun kelor terhadap kuantitas air susu ibu (ASI) pada ibu menyusui bayi 0-6 bulan di Wilayah Kerja Puskesmas Sumur Batu Kota Bandar Lampung Tahun 2019.

Sejalan dengan teori yang dikemukakan oleh Zakaria (2016) Pada keadaan fisiologis menyusui, kebutuh- an gizi ibu meningkat karena kebutuhan untuk memproduksi ASI. Hasil penelitian Rahayu menyatakan bahwa faktor

Eka Trismiyana ${ }^{1}$, Mei Kurnia Pitaloka ${ }^{2}$

${ }^{1}$ Dosen Keperawatan Universitas Malahayati Bandar Lampung. Email: ekatrismiyana@gmail.com

${ }^{2}$ Mahasiswi keperawatan Universitas Malahayatl Bandar Lampung. Email : mei722482@gmail.com 
makanan

berpengaruh signifikan terhadap produksi ASI selain faktor psikis dan isapan bayi. Tanaman kelor (Moringa oleifera) merupakan bahan makanan lokal yang memiliki potensi untuk dikembangkan dalam kuliner ibu menyusui, karena mengandung senyawa fitosterol yang berfungsi meningkatkan dan memperlancar produksi ASI (efek laktagogum).Secara teoritis, senyawa-senyawa yang mempunyai efek laktagogum diantaranya adalah sterol. Sterol merupakan senyawa golongan steroid.

Sejalan dengan penelitian yang dilakukan oleh Saelan (2018) dengan judul "Pengaruh Terapi Hypnopunturbreastfeeding Dan Air Seduhan Daun Kelor Terhadap Produksi ASI" Hasil uji hipotesis Terdapat perbedaan produksi ASI antara sesudah diberikan terapi brest care dan air seduhan daun kelor dan sesudah diberikan akupuntur, hipnobresfeeding, air seduhan daun kelor hal tersebut tampak dari nilai sig 0.000 lebih kecil dari 0.005 yang artinya terdapat pengaruh terapi hypnopunturbreastfeeding dan air seduhan daun kelor terhadap produksi ASI.

Selain kerja hormonal produksi ASI juga ditentukan oleh reflex akibat isapan bayi. Isapan bayi mengakibatkan terjadinya dua reflex yang menyebabkan ASI keluar pada saat dan jumlah yang tepat. Kedua reflex tersebut adalah reflex produksi ASI atau reflex polaktin yang dirangsang oleh hormone prolactin dan reflex pengaliran/ pelepasan ASI (let down reflex) yang dipengaruhi oleh hormone oksitosin.

Menurut

peneliti

Menurut teori daun kelor yang mengandung antioksidan nonenzimatik seperti vitamin A (beta carotene), vitamin C dan vitamin $E$ yang dapat mengurangi kerusakan DNA17 serta senyawa fitosterol. Tanaman kelor (Moringa oleifera) merupakan bahan makanan lokal yang memiliki potensi untuk dikembangkan dalam kuliner ibu menyusui, karena mengandung senyawa fitosterol yang berfungsi meningkatkan dan memperlancar produksi ASI (efek laktagogum).Secara teoritis, senyawa-senyawa yang mempunyai efek laktagogum diantaranya adalah sterol, efek laktogagum merupakan reflek yang dapat merangsang pengeluaran oksitosin, sehingga merangsang pengeluaran ASI.

Dalam penelitian ini terdapat 1 responden yang tidak mengalami peningkatan ASI hal ini disebabkan karena jumlah ASI ibu sebelum dilakukan intervensi berada pada 110cc, dan setelah dilakukan intervensi tetap 110 cc, faktor psikologis dan kelelahan pada ibu juga dapat mempengaruhi produksi ASI sehingga tidak mempenmgaruhi perubahan sebelum dan sesudah.

Eka Trismiyana ${ }^{1}$, Mei Kurnia Pitaloka ${ }^{2}$

${ }^{1}$ Dosen Keperawatan Universitas Malahayati Bandar Lampung. Email: ekatrismiyana@gmail.com ${ }^{2}$ Mahasiswi keperawatan Universitas Malahayatl Bandar Lampung. Email : mei722482@gmail.com 


\section{KESIMPULAN}

Rata-rata kuantitas air susu ibu (ASI) pada ibu menyusui bayi 0-6 bulan sebelum diberi seduhan daun kelor di Wilayah Kerja Puskesmas Sumur Batu Kota Bandar Lampung Tahun 2019, dengan mean 72,50 standar deviasi 25,317 standar eror 4,622 min 30 max 110. Rata-rata kuantitas air susu ibu (ASI) pada ibu menyusui bayi 0-6 bulan sesudah diberi seduhan daun kelor dengan mean 97,17 standar deviasi 17,601 standar eror 3,214 min $60 \max 130$. Hasil uji t-tes $p$-value $0.000(<0.05)$ yang artinya terdapat pengaruh pemberian seduhan daun kelor terhadap kuantitas air susu ibu (ASI) pada ibu menyusui bayi 0-6 bulan di Wilayah Kerja Puskesmas Sumur Batu Kota Bandar Lampung Tahun 2019.

\section{SARAN}

Diharapkan hasil penelitian ini dapat memberikan wawasan sekaligus sebagai ilmu pengetahuan bagi perkembangan ilmu keperawatan terutrama bagi ibu dan anak yang dapat disosialisasikan dikalangan institusi kebidanan dan dapat digunakan sebagai masukan bagi klien agar dapat mengetahui bagaimana cara menambah kelancaran ASI pada masa menyusui, karena ASI yang lancar akan memberikan banyak manfaat bagi anak.

\section{DAFTAR PUSTAKA}

Arikunto.

(2013).

Prosedur

Penelitian Suatu

Pendekatan Praktik.

Jakarta: Rineka Cipta.

Astutik, R. Y. (2015). Asuhan Kebidanan Masa Nifas Dan Menyusui. Jakarta: Trasn Info Media.
Fikawati, S. (2015). Gizi Ibu dan Bayi. Jakarta : Raja Grafindo.

Handayani., Arifin. (2018).
Pengaruh Daun Kelor
(Moringa Oleifera)
Terhadap Peningkatan
Kadar Hemoglobin Pada
Wanita Usia Reproduktif
Yang Mengalami Anemia.
Mataram : Stikes Yarsi.

Iswari, I. (2017). Gambaran Pengetahuan Suami Dari Ibu Menyusui (0-6 Bulan) Kabupaten Selumatahun. https: / /jurnal.

unived.ac.id/ index. php/ $\mathrm{JM} /$ article/view/505.

Kemenkes RI. (2014). Panduan Gizi Seimbang.

Krisnadi. (2015). Kelor Super Nutrisi. Kelorina. Com: Lembaga Swadaya Masyarakat.

Maryunani, A. (2015). Inisiasi Menyusu Dini Asi Eksklusif Dan Manajemen Laktasi. Jakarta: Trans Info Media.

Notoatmodjo. (2018). Metodologi Penelitian Kesehatan. Jakarta: Rineka Cipta.

Profil Dinkes Provinsi Lampung. (2018). Cakupan Pemberian ASI Ekskluisif.

Saelan., A. (2018). Pengaruh Terapi Hypnopunturbreastfeedin g Dan Air Seduhan Daun Kelor Terhadap Produksi Asi. Surakarta: Stikes Kusuma Husad:.

Eka Trismiyana ${ }^{1}$, Mei Kurnia Pitaloka ${ }^{2}$

${ }^{1}$ Dosen Keperawatan Universitas Malahayati Bandar Lampung. Email: ekatrismiyana@gmail.com

${ }^{2}$ Mahasiswi keperawatan Universitas Malahayatl Bandar Lampung. Email : mei722482@gmail.com 
Sihombing. (2017). Hubungan Pekerjaan Dan Pendidikan Ibu Dengan Pemberian Asi Ekslusif Di Wilayah Kerja Puskesmas Hinai Kiri. Sekolah Tinggi Ilmu Kesehatan Putra Abadi: Langkat

Vivian. (2011). Asuhan Kebidanan Pada Ibu Nifas. Jakarta Selatan: Salemba Medika.

Walyani., S., Elisabet. (2015). Asuhan Kebidanan Masa Nifas dan Menyusui. Yogyakarta: Pustaka Baru Press.
Wiguna, I. (2018). Pasar Dan Khasiat Kelor. Depok: PT Trubus Swadaya.

Zakariah., B., H. (2016). Pengaruh Pemberian Ekstrak Daun Kelor Terhadap Kuantitas Dan Kualitas Air Susu Ibu (Asi) Pada Ibu Menyusui Bayi 0-6 Bulan. Makassar: Unvesitas Hasanuddin. 